\title{
特集 I【論説】 道路整備と住民合意
}

\section{ドイツの道路事業と住民合意の仕組み}

Consensus building and planning process in federal road planning in Germany

Masako MUROTA : Musashi Institute of Technology

Faculty of Environmental and Information Studies

室田 昌子*

This paper aims to clarify consensus building process in German road planning, and consider how to adjust interests between the environmental interests and traffic interests in road planning. German road planning system has four main stages, demand planning, line decision procedure, plan establishment procedure, and land acquisition procedure. Each stage has citizen's consensus building system except demand planning. Plan establishment procedure is the most important system, because all interests have to be adjusted at the stage. I point some advantages and disadvantages in German system, and suggestions to Japanese system.

keywords : Consensus building, Planning process, Interest adjustment, Citizen’s participation, Germany, 合意形成，計画プロセス，利害調整，住民参加，ドイツ

\section{1.はじめに}

ドイツは，国民の環境意識が高く，環境保全な どの活動が活発な国として知られている。実際, 多くの環境保全団体があり，環境問題に対する住 民レベルのキャンペーンや監視活動, 環境保護活 動が活発であり，全国的な環境保護のネットワー クも確立している。環境教育に対する取り組みも 熱心であり, 小学校, あるいはそれ以前から, 多 様な環境教育のプログラムを持っており, 環境意 識のさらなる向上を目指している。このような国 民の高い環境意識を背景に，政府も環境保護に熱 心な取り組みを行なっている。

一方でドイツは，道路事業，特に高速道路整備 の活発な国であり，2001年現在で約 $11,800 \mathrm{~km}$ の連 邦長距離道路（アウトバーン）の整備をしている。
さらに旧東ドイッの地域は道路整備が不十分とさ れ, 緊急の政治的課題に位置づけられており, 連 邦長距離道路を始めとした道路整備が実施されて いる。また，ドイッはEUにおける経済的地位を 確保するためにも, 今後とも活発に連邦長距離道 路を整備する計画であり，旧東ドイツのみならず 道路整備に対してかなり前向きな姿勢を持ってい る。

しかしながら，一般的に環境保護を重視すれば， 道路整備の中止, 特に環境影響が大きい高速道路 の整備の中止を求める傾向は高まるだろう。環境 保護と道路事業は対立する局面が多く, 従って, このような対立を何らかの形で打開できる方法が なければ，環境保護に熱心な国で，高速道路の整 備を積極的に進めることは困難であろう。

本稿では，このようなドイツの事情を背景に， 室田 昌子*（むろた まさこ）正会員・武蔵野工業大学環境情報学部講師 
ドイッではどのような方法で道路整備を進めてい るのか，特にこの相対立する価值観のなかで，い かに合意を形成しつつ事業を進めているのかを検 討したい。その上で，ドイッの仕組みからみた日 本における道路事業の住民合意形成に関する制度 上の課題をまとめたい。

\section{2. ドイツの道路事業の事業化プロセスと合 意形成}

ドイツの道路事業は, 連邦長距離道路, 連邦道 路, 州道路, 郡道路, 市町村道路などの道路のレ ベルにより，その進め方は異なり，また連邦国家 であるため, 州法の規定によって, 州によっても 進め方に違いがある。連邦長距離道路は, 事業を 実施する上で最も多くの段階別の住民参加方法が 規定されており, 複雑ではあるものの一貫性のあ る事業化プロセスが体系化されている。ここでは 連邦長距離道路を中心に, その進め方と合意形成 プロセスを紹介する。

\section{1 連邦長距離道路の事業化プロセス}

連邦長距離道路は, 需要計画 (Bedarfsplan), 予備計画 (Vorplanung), 路線決定手続き (Linien, bestimmungsverfahren), 予備設計 (Vorentwurf), 計画確定手続き (Planfeststellungsverfahren), 用 地取得手続き（Grunderwerb）などの段階があり， このなかに, 環境影響評価 (Um weltvertraeglichkeitspruefungen)の手続きが各段階で組 み込まれる。

\section{1.1 需要計画}

需要計画は, 全国の連邦長距離道路の各路線の 必要性を検討し，国レベルの広域道路計画を策定 するものであり， 5 年ごとに見直しをする。各路 線の必要性は, (1)交通上の重要性と費用対効果を 検討する交通需要項目，(2)自然保護地域などの環 境影響を把握する環境項目，(3)国土整備計画や都
市建設との整合性を検討する広域的土地利用項目 などから，総合的に評価し優先順位を決定する。 決定にあたっては，各州政府等からの意見を把握 し，連邦議会がこれを決定する。優先順位を決定 するための根拠デー夕は公開され，誰でも意見を 述べることはできるが，これらの意見に対する回 答義務はなく，また住民と直接的に協議を行う場 はない。

\section{1 .2 予備計画〜路線選定手続き}

需要計画を受けて基本的に優先順位の高い路線 から，州政府の道路担当部局が予備計画を作成す る。予備計画では, 特定路線に関する概略の線形 や構造と費用概算を検討し, 複数の路線から比較 が行えるように，技術的可能性がある限り複数路 線の概略計画を作成する。

予備計画に基づいて, 路線選定手続きでは, 複 数の比較路線から最も適切な優先路線を決定する。 路線選定手続きは, 複数路線の比較評価の結果と 関係団体と住民の意見をもとにして，優先路線を 絞りこむもので, 環境影響評価と国土整備計画と の適合性の判定を含めて行う。比較評価の項目は, 州等による差があるものの, (1)交通項目（交通混 雑緩和や利便性改善等の効果, 建設コスト, 管理 費用など)，(2)環境項目（自然保護区域，水利保護 区域，景域保護区域，生態系，河川水路，地下水 系，保養地など)，(3)国土整備項目（国土整備計 画 - 公共計画との整合性 - 効果, 地域構造改善, 優良農地・森林地・居住地・工業団地との適合性 など）がある。

路線選定手続きのプロセスは, 図 1 で示すよう に, 複数路線の比較評価をもとに，まずは関係機 関との協議や住民説明会を開催し，これらの意見 を加えて優先路線案を作成する。州の国土整備担 当部局が比較評価報告書と優先路線案, 関係機関 や住民の意見の議事録とそれに対する判断を記述 した報告書を，関係機関に送付し，住民への公告 
縦覧を行う。この計画に対して関係機関や住民は, 一定期間内に意見書を提出でき, 関係機関や住民 からの意見に対しては，道路担当部局はすべて回 答をする必要がある。

路線検討時の協議や説明会などによって出され た関係機関や住民の意見は，公告縦覧時に公表さ れ，また，公告縦覧の際に提出された意見書とそ れに対する回答も公表される。優先路線案を提示 する上での根拠が明らかになるとともに，その後 の意見やそれに対する回答も公表され，どのよう な反対がありそれに対して事業者側はどのように 考えたかが明らかとなる。なお関係機関との協議 内容は，州によって公表の程度に差があるが，基 本的には公表という姿勢があり透明性の高い手続 きと言えよう。

また，意見書に対する回答への反対が多い場合 などは，さらに協議や説明会を実施する。道路担 当局はこれらすべての意見を踏まえて判断し，国 土整備担当部局にこれらの意見のとりまとめを添 付して優先路線を提示する。

この段階で比較検討されるのは広域利益と地域 利益であり，個人の利益は対象外とされ，広域や 地域にとってよりマイナスが少なくプラスの大き い路線案を決定する。従ってこの段階の決定は, 公的な実施計画者に対して拘束力を発揮するが, 個人に対しては拘束力をもたない。

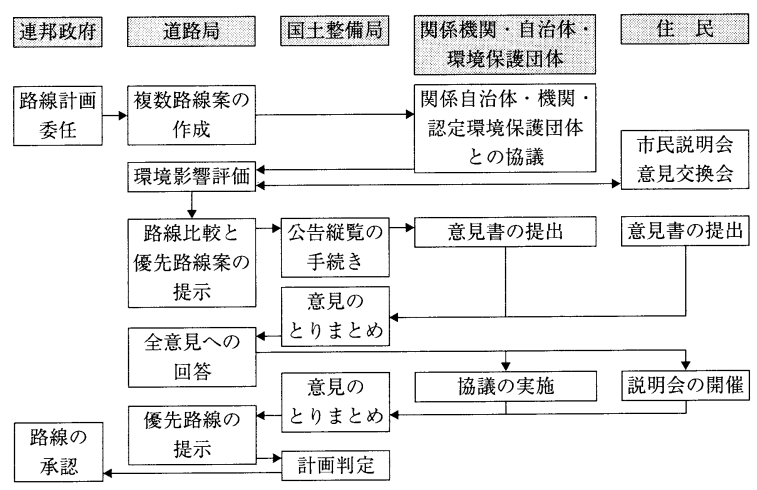

図 1. 路線選定手続き
近年ドイッでは，早期における住民参加の必要 性が指摘され，この段階からの住民参加を積極的 に行うことが，その後の計画を円滑に進める上で 重要であると言う認識が広まっている。従って, 法 制度にもとづかない説明会の開催や意見交換がな され，住民の意見を取り入れる工夫がされている。

\section{1 .3 予備設計 計画確定手続き}

予備設計は, 測量に基づく詳細設計であり, 計 画確定手続きの実施に向けて，1000分の 1 から必 要に応じて50分の 1 のスケールの道路設計図や横 断面図を作成する。

計画確定手続きは，予備設計を受けて計画を確 定するための手続きである。補償金額を除く全て の利害を対象とした協議と聴聞を行うもので，計 画確定資料の公告縦覧と聴聞を行う「聴聞手続き (Anhoerungsverfahren)」と, 聴聞手続きを踏ま えて計画を確定する「計画確定決定（Plantestellungsbeschluss)」の 2 つに区分される（図 2 参照）。

事業用地等の測量結果を踏まえた個別具体の影 響が協議され決定されるもので，日本の都市計画 事業で言えば，都市計画事業認可段階に該当する。 判断にあたっては, (1)全ての利害を比較衡量して 最も不利益の少ない, または利益の大きい計画か どうか, (2)事業によって発生する不利益は, 法規 制の範囲内か，あるいは勘案すべき個別の事情が あるかどうかなどを把握し，(3)不利益に対する対 策が適切に講じられているかを把握して判断する。 計画確定手続きで勘案される利害は，(1)環境項 目（騒音振動, 排出ガス, 土㙵, 地下水, 動植物, 自然保護区域 - 水利保護区域, 気候, 文化財 - 遺 跡, 景域保護などの影響と対策, 事故対策), (2)公 共公益施設項目 (上下水道・排水施設, 電気・ガ ス, 河川などの変更や対策), (3)土地利用項目（農 用地・森林地, 漁業・水面, 鉱山などへの影響や 対策, F・B プランとの適合性), (4)交通項目（地 域道路・鉄道の交差や対策, アクセス道路, 地域 
交通への影響など）などがある。

具体の手続きとして「聴聞手続き」では，まず 関係する公共公益機関に計画確定資料を送付し, 関係市町村に住民への公告縦覧用の計画確定資料 を送付し，関係機関はそれに対する見解を，住民 は異議申立を定められた期間内に行う。これらの 見解や異議申立に対して, 州政府等の聴聞部局が 聴聞会を開催し, 道路部局側と関係機関や住民と の協議をする場を設ける。この結果，計画を変更 する場合は計画確定資料を作成し直し, 再度, 聴 聞手続きを行う。「計画確定決定」は，聴聞手続き を受けて, 州政府の計画確定部局が決定, 留保, 決定の取り消しを行うもので，聴聞会で合意に至 らなかった事項については計画確定部局が裁定す る。計画確定決定に異議がある場合は, 行政裁判 所に提訴できる。

環境影響への適合性も，この手続きのなかで集 中的に検討される。例えば, 騷音, 排出ガス, 排 水, 土壤影響などの測定結果や予測值に対して, 各法律や要綱等に定められる基準值との適合性や, 測定方法の適切性が検討される。異議がある場合 は, 異議申立をし, 異議がもっともな場合は, 計 画の変更や対策が講じられる。

\section{1 .4 用地取得手続き}

用地取得手続きは，一般的には計画確定決定以 降，さらに行政裁判所の判決が確定した以降に開 始される。計画確定手続きや判決によって計画が 変更されるケースがあるためである。しかしケー スによって異なり, 行政訴訟については裁判の様 子を確認しつつ勝訴が確信できれば判決が出る前 でも開始する。

用地取得手続きでは, 協議を参加するのは地権 者などの権利関係者のみであり, 補償額と方法の みが協議対象となる。合意に達しない場合は収用 行政局が担当し, さらに合意に達しない場合は収 用手続きを開始し，口頭弁論を経て収用行政局が 収用裁決をし，裁決の執行を行う。

\section{3. ドイツの道路事業と住民合意方法の特徴}

\section{1 事業段階別の住民との合意決定方法}

道路事業を決定する上での反対理由として住民 から指摘されるのは, (1)事業の必要性に対する疑 問や反対，(2)なぜその地域に整備するのかという 立地の適切性, (3)周辺環境の悪化に対する懸念や 対策, (4)補償金額への不満などが, 主要な点とし てあげられる。ドイツの道路事業の進め方の特徴 は，これらのポイントを事業段階別に順次検討し， 所定手続きを経て決定するというシステムが構築 されていることである。

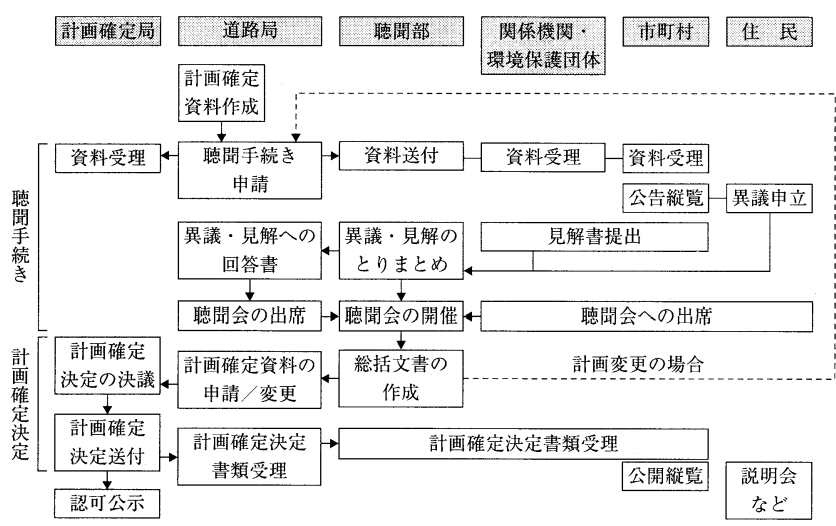

図 2. 計画確定手続き
まず，事業の必要性に関する反対は，「既 存道路や鉄道などで代替できるのではな いか」, 「道路整備により自動車利用を促進 し混雑緩和につながらないのではないか」, 「他の地域でもっと必要性の高い道路があ るのではないか」と言った点が代表的なも のとしてあげられよう。これに対してその 根拠を明示する役割を果たしているのは, 需要計画である。各路線の需要を指標化し ているので, 一般住民も理解することがで 比較評価する際の項目や基準は公表され 
き, 指標化などの方法で疑問があれば指摘するこ とができる。根拠を明らかにして連邦議会で決定 する方式であり，トップダウン方式で市民参加の 機会はないが，理由はわかりやすいと言える。

第二に，立地の適切性については，「地域の環境 に対して多くのマイナスがあるので他の地域に整 備してほしい」，「他の地域の方がもっと適してい るのではないか」「さらに理由はともかく自分の 住む地域では整備をしないで欲しい」と言う指摘 や要望があるだろう。路線の立地場所が適切かど うかについては，路線決定手続きが対応している。 路線の比較評価では,「自分の住む地域だけは整 備しないで欲しい」と言った理由はエゴとして排 除されるが，合理的な理由があるものは地域利益 として比較評価の対象となる。例えば「優良農地 を分断することにより，地域の農地の質が大きく 低下する」「計画中の住宅地開発が不可能になる」 「居住地に近く, 騒音, 振動, 排出ガスなどで深刻 な影響がある」など，地域に与える影響を何でも 指摘できる。これらは関係機関や住民が参加して 指摘することにより，より多様で詳細な視点から の地域利益を検討対象に加えることができる。

また，環境保護団体は環境面で発生する様々な 不利益を詳細に指摘するが，特に認定環境保護団 体 ${ }^{(1)}$ は公共公益機関と同じ位置づけとなっており, 早期から事業者との協議が行われる。代表的な認 定環境保護団体は組織化されており, 周辺地域住 民の環境に対する意見を吸収し賛否を確認しつつ 協議に参加しているので，周辺住民の環境に対す る意見を反映する役割を担っている。環境影響評 価は，最大の争点であり，特に早い時期から協議 をすることにより，環境保護団体と周辺住民のか らの合意が少しでも得やすい計画を作成すること が重視されている。

第三として，周辺環境悪化の懸念や対策への要 望がある。高速道路等が整備されれば，周辺環境 面などで何らかの影響が発生することは避けられ
ないが，これに対しては，漠然とした一般的な不 安や懸念と，実際に発生する個別具体の影響を把 握し適切な対策をたてて欲しいと言う要望がある。 後者にあたる個別具体の影響については，計画確 定手続きの中で詳細に検討される。計画確定手続 きは, 建物や用地を測量し, 騒音振動や大気污染 などの各影響について，個々の建物にどのような 負荷がかかるかを測定した上で協議するので，個 別具体の協議ができる。代わりに漠然とした不安 については，どの項目がどの程度不安かを住民側 は明確にして協議することが求められ，漠然とし た内容は却下される。

最後に，補償金額に関する不満であるが，これ は計画確定手続きまでは協議の対象外であり，用 地補償の段階で初めて協議される内容である。最 初に提示された金額以外の金額になる可能性は少 なく，協議の余地は少ない。また，機械的に収用 手続きに移行する州もあり，例えばへッセン州で は 3 回交渉して合意に達しない場合は収用手続き を開始しており，用地取得手続きが長期化する ケースは少ない。

このように, 事業の必要性, 立地の適切性, 周 辺環境面での適合性, 補償金額が，各事業段階ご とに順番に明示的に検討され，所定手続きを経て 決定される。これらの事項は，日本でも住民から の反対や要望が極めて多い点であり，それぞれの 関心事項に対応した，わかりやすい段階別の検討 方法と決定方法がドイツの特徴として指摘できる。

\section{2 計画確定手続きの実態と役割}

計画確定手続きは, 全ての利害を協議対象し, 権利を拘束する効力を持っており，決定手続きと しては最も重要な位置づけにある。計画確定手続 きは, 州による違いはあるものの, 連邦長距離道 路，連邦道路，州道路，郡道路等で実施されてお り，公共事業を決定するうえで広く活用されてい る制度である。多くの利害関係を集中的に取り扱 
い，全ての関係機関からの許認可を得，関係住民 からの異議を解決し決定することを目的としてお り，一定期間内に集中的に協議や審議を行うこと により効率化が図れると考えられて設置された制 度である。

計画確定資料は，道路の解説書，道路の計画図 に関する資料（概略図，複数路線検討図，路線高 低図，道路設計図，横断面図）用地や建物資料リ ス卜，景域保護付随計画，環境影響評価資料，騒 音や水利・排水対策図，地質等の各図面など膨大 である。このような資料を一般住民が一読して理 解することはかなり難しい。従って，事前の説明 会の開催や，個別の説明や相談などを行い，関係 者に情報を徹底することが重視されている。

住民への説明は，例えばノルトラインベスト ファーレン州A44のように，専門の事務所を設置 し，周辺の状況と完成後の様子を映像化したり， 巨大な模型を制作し説明要員をおくなどの工夫を し，少しでも疑問のある住民に対して，計画確定 手続き開始前から丁寧に説明をし意見を反映する ような努力をした例もある。

計画確定手続きは, 概ね $10 \mathrm{~km}$ 程度ごとに実施す る。図 1 は, バイエルン州の南東地域ミュンヘン からポッキングを結ぶA94の事業経過であるが, 当地域では, $10 \sim 20 \mathrm{~km}$ 程度に区切って実施されて

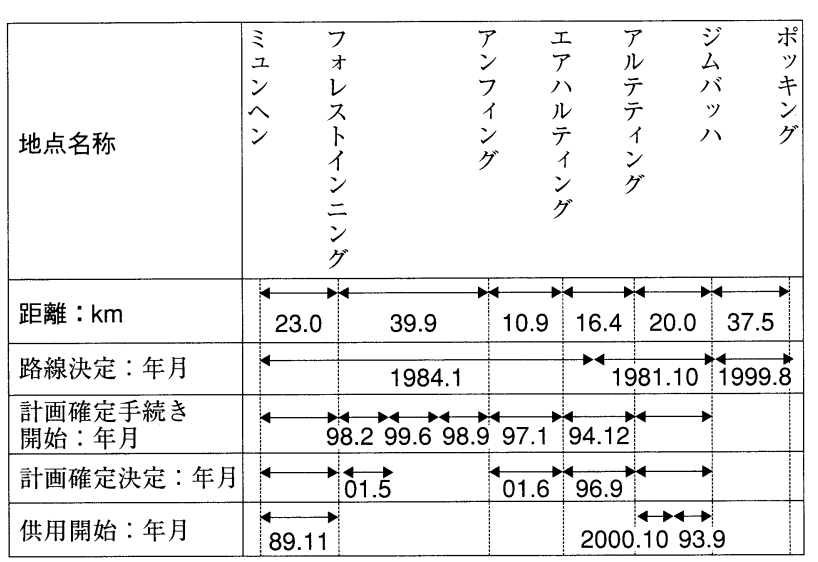

図 3.A94の事業経過
いる。隣接する路線の関係機関や住民らも，計画 確定手続きの利害関係者とされており，公告縦覧 や異議申立の対象となっている。

計画確定手続きに要する時間は，手続き開始か ら計画確定決定までで $2 ， 3$ 年を要する。説明会 の開始から 4 年間は，計画に関連する土地の変更 禁止措置が発動されるので，従って一般的には 4 年以内に終了する。しかし，住民や関係機関から 多くの異議が出され，計画が変更され，聴聞手続 きを何度もやり直す場合は時間が長期化するケー スもある。

計画確定手続きでは，周辺環境に限らず全ての 異議を申し立てることができる。実際に，異議申 立の内容をベルリン州のA113で見ると, (1)事業の 必要性，(2)路線の選定，(3)土地利用計画に関する もの，(4)大気污染，(5)騒音振動，(6)水質，(7)景域 保護，8動植物，9居住環境，(10排水，地下水, (11)土壤，12)文化財遺跡，13景観，(14)安全対策，15) 公共施設との接続，16)工事，17)手続きに関するも の，18)用地取得・補償などがある。

すなわち，事業の必要性や路線選定に関する内 容も，異議申し立てをすることができる。しかし これらの異議に対する回答は，これまでの検討の 正しさが強調され，通常は，反論され却下される。 一方，異議に対しての検討がなされているのは，

(4)から17) と，18)の補償以外の項目である。例 えば,「自分の家は騒音限界值を超えているの ではないか」，「地下水が污染させていないか 定期的なチェックをして数值を公表してほし い」，「敷地へのアクセスが分断される」など といった異議に対しては個別に再検討が加え られる。

住民の最大の関心は，やはり自分の住宅や 土地に及ぼされる影響と言えるが，計画確定 手続きの中で自分たちに及ぼされる影響に不 安や懸念がある内容について, 事業者側に再 調查を依頼することができ，問題がある場合 
は, 対策を講じさせることができる。また, 勘案 してもらいたい家庭の事情などがある場合, それ を申立て, 特別の対策を講じてもらうことも事情 に応じて行われている。

一方で，聴聞会で異議申立をしなかったことに ついて，手続き終了後に異議申立をすることや提 訴することは無効とされている。住民参加の考え 方として，住民は自分にとっての不利益が発生す る恐れがある場合, 計画確定資料を参照し, 事業 者からの説明を経て, 自分で異議申立をする責任 があると言う考え方がベースにある。従って，住 民がその責任を果たさずに計画が確定されてしま うと, 後から苦情を言っても効果がなく却下され てしまうことになる。これは, 後から新たな問題 点が際限なく提示されることを防ぐ目的をもって おり，定められた期間内に全ての異議申立をする ことを徹底することにより効率化を図っていると 言える。

\section{4. ドイツの合意形成制度の特徴と日本にお ける課題}

\section{1 ドイツの道路事業における合意形成制度 の特徴}

ドイツの道路事業における住民との協議制度は, 住民への説明会の開催，住民からの意見書提出や 協議等を行う正式な手続きとして, 路線決定手続 き, 計画確定手続き, 用地取得・土地収用手続き がある。

この特徴をまとめると，(1)事業段階別に協議事 項を明確にした協議・決定システムとして体系化 されており, 順次決定し検討事項を絞り达む仕組 みとなっていること, (2)路線選定手続きでは, 早 い段階で認定環境保護団体との協議を行い，特に 環境に関する侵害を早期計画段階から相互に検討 し合うこと, (3)路線選定手続きでの住民からの意 見に対しては回答義務があり，路線選定手続きや 計画確定手続きなどで反対意見が多い内容につい
ては, 繰り返し再検討する仕組みとなっており, フィードバックシステムがあること, (4)関係機関 や住民からの意見は, 事業者側の回答と併せて公 表され, 透明性が高いこと, (5)行政処分行為とな る計画確定手続きが最も重要な位置づけにあり, 全ての利害について異議を申し立て集中的に協議 を行う仕組みとなっており，集中的な審議により 効率化が図れること, (6)環境影響評価を各段階で 実施するが，計画確定手続きのなかでは，個別の 土地や建物の具体の予測值をもとに協議するので, 明確な対策が講じられる一方, 漠然とした不安や 鷍念は却下されること, (7)異議申立を期間内に行 うことは住民側の責任であり, 異議申立終了後に 申立を行っても排除され，このことは事業の効率 化に大きな効果をあげていること，8用地取得時 には, 補償金額など交渉の余地がなく機械的に進 めていることが指摘できる。

一方で, ドイツの制度について幾つかの問題点 も指摘できる。第一に, 需要計画は法的効力を有 するものの住民参加の仕組みはない。これは, 国 土全体という広域地域の順位を決定する上で特に 一部の住民らの意見を聞くことは，かえって不公 平になると言う考え方があるためである。しかし 事業の必要性に対する住民の疑問に答える場が実 質的にないために, 計画確定手続きの段階で非常 に多くの異議が出されており, 賛否両論あると考 えられる。第二に, 路線選定手続きから計画確定 手続きの間には, 計画の精度に大きな隔たりがあ る。従って, この間の参加の重要性が指摘され, 州によっては積極的に参加が進められているが, 法定の参加システムはない。第三に, 路線選定手 続きも計画確定手続きも，区間を区切りつつ検討 を進めるが，ある区間を確定することは次の区間 の始点を確定してしまうことであり，隣接する区 間の検討を十分に行っていない場合など矛盾を生 じる可能性がある。第四に, 公開縦覧する資料に は規定があるものの, 説明方法は各自治体等に任 
されており，きちんとした説明がされなければ, 膨大で専門性の高い資料は住民から理解されず, 参加は形だけのものとなってしまう可能性がある。 第五に，特に計画確定手続きにおける調査は詳細 であり，公開縦覧資料も膨大であるために，その 費用が高いこと，第六に，環境面での厳しいルー ルや基準の遵守と各利益の比較による計画づくり が行われているが, 交通上の重要性が高く, かつ 環境面での侵害が大きい場合は，トンネル化など 環境侵害を避けるための費用が膨大化することな どがあげられる。ただし費用面については，環境 保全と道路事業を両立するためのコストと考えら れる。

\section{2 日本での課題}

ドイッの道路事業での合意形成の仕組みは, 環 境をはじめとした様々な利益について早期段階か ら詳細な協議や説明会が行われ, 計画へのフィー ドバックがなされるとともに, 計画確定手続きで は詳細な調査により環境面での侵害がないことを 公表した上で，さらなる協議やそれに基づく対策 が実施される。一方で，一定期間内での集中的な 検討や, 期間内での異議申立責任とその後の異議 の排除などで効率化を意識した仕組みを有してお り，特に用地取得では協議の余地がほとんどなく 短期間で終了することが特徵と言える。

一方日本は, 早期段階での住民参加が不十分で あり，住民意見を計画に反映するフィードバック の制度が確立されておらず，事業化が近づくにつ れ住民との間に軋軪を生じ，用地取得段階では対 立が表面化し難航するというケースが少なくない。

PIの導入により早期段階からの住民参加が日本 でも進められているが, ドイッの優れた点を参考 にすれば，(1)意見に対する回答や，合理性のある 意見を計画に反映するなどのフィードバックをす ることが，参加の意義を確保する上で必要である こと，(2)これらを公表することにより透明性が高
まるだけでなく, 意見に対する住民側の責任意識 も向上することが指摘できる。

また，日本の環境影響評価は，都市計画決定時 に併せて公表され，住民にとっては不明な点が多 い段階で計画が決定される。ドイツの環境影響評 価では, 日本で言えば都市計画事業認可段階に最 終的な公表がなされるので, 住民はどの土地や建 物にどの程度の影響が発生するのか詳細に把握す ることができ，また全て公開されるため他地域の 住民の状況も把握できる。日本の事業化段階では, 用地説明会や測量説明会が行われるが, 現場での 裁量が大きく, 対策が全て公表されるわけではな いので不透明である。

計画確定手続きは, 既述のような問題を有して いるものの, 事業化段階での透明性を向上させる 上で大きな効果があると考えられる。日本でもこ のような制度を導入することにより，不公平な対 策の解消やゴネによる協議の長期化を防止できる のではないかと考える。結果として，その後の用 地取得においても，ドイッで確認されるように， 公平性と円滑性を向上させることができるのでは ないかと考えている。

補注（1)連邦自然保護法BNatSchG（2002）第59条に 基づいて認定を受けた環境保護団体

\section{参考文献}

1 ）室田昌子（2002）「ドイツの連邦道路事業における 計画調整システムと概略計画段階での調整方法 に関する考察」日本都市計画学会論文集No.37 pp409〜 pp414

2 ）室田昌子（2004）「ドイツの計画確定手続きに見 る利害関係者との調整の仕組みに関する考察」日 本都市計画学会論文集No.39-3 pp433 pp438

3 ）室田昌子（2004）「住民合意に着目した公共事業の 用地取得制度に関する改善方策の考察—ドイッ の連邦長距離道路事業精度と比較して一」運輸政 策研究Vol.7 No.3 pp10 pp18 